Interdisciplinary Studies of Complex Systems

No. 19 (2021) 141-155

(C) I. Afanasiev, T. Bielofastova, L. Novokhatko, D. Kharamurza

https://doi.org/10.31392/iscs.2021.19.141

$\left.37.091 .3: 81^{\prime} 243\right]: 355.233 .2$

\title{
IMPROVING THE TRAINING OF MEDIA PROFESSIONALS AS A COMPLEX SYSTEM
}

\author{
Illia Afanasiev ${ }^{12}$, Taisiia Bielofastova ${ }^{1,3}$, Leonid Novokhatko ${ }^{1,4}$, \\ Daria Kharamurza ${ }^{1,5}$

\section{У ДОСКОНАЛЕННЯ ПІДГОТОВКИ МЕДІАФАХІВЦІВ ЯК СКЛАДНОЇ СИСТЕМИ}

\author{
Ілля Афанасъєв, Тайсія Белофастова, Леонід Новохатъко, \\ Дар'я Харамурза
}

\begin{abstract}
This article analyzes the training of media professionals as a complex system. Structural components that provide effective functioning of this system have been identified. The features of monitoring of the learning process, its results analysis and timely correction of emergent properties are revealed. The article also argues the necessity for a multivector, practically-oriented organization of training future specialists in the industry. Particular attention is paid to the importance of innovation in the higher education's learning process. The complex system of organizing the training of media professionals in the «Advertising and Public Relations» major is considered based on the example of the successful case study of Borys Grinchenko Kyiv University.
\end{abstract}

Keywords: media, media professionals, complex system, higher education, innovation, monitoring

Анотація. У статті аналізується підготовка медіафахівців як складна система. Визначено структурні компоненти, які забезпечують її ефективне функціонування. Розкрито особливості моніторингу освітнього процесу, аналізу результатів та своєчасної корекції системних властивостей. У статті також аргументовано необхідність багатовекторної, практикоорієнтованої організації підготовки майбутніх спеціалістів галузі. Окрема увага приділяється важливості впровадження інновацій у навчальний процес вищої школи. Складну систему організації підготовки медіафахівцівза за напрямом «Реклама і зв'язки з громадськістю» розглянуто на прикладі успішного кейсу Київського університету імені Бориса Грінченка.

Ключові слова: медіа, медіафахівці, складна система, вища освіта, інновації, моніторинг

\footnotetext{
${ }^{1}$ Borys Grinchenko Kyiv University, Kyiv, Ukraine.

2 i.afanasiev@kubg.edu.ua, https://orcid.org/0000-0002-2736-5021

3 t.bielofastova@kubg.edu.ua, https://orcid.org/0000-0003-2730-8120

${ }^{4}$ I.novokhatko@kubg.edu.ua, https://orcid.org/0000-0003-1104-6488

${ }^{5}$ d.kharamurza@kubg.edu.ua, https://orcid.org/0000-0003-4420-6767
} 


\section{Актуальність дослідження}

У світовій науці склався широкий консенсус щодо характеристики освіти як складної системи. Таке тлумачення постає з аналізу відомих наукових робіт, присвячених теорії складних систем. Достатньо згадати праці Яніра Бар-Яма та Гірокі Саяма (Bar-Yam, Y., 2003; Sayama, Hiroki, 2015) $[1,5]$. Безпосередньо теза про освіту як складну систему грунтовно доводиться у роботах М. Джейкобсон, Дж. Левін, М. Капур $[2,3,4]$.

Консенсусним характеристикам основних рис складної системи, які містяться у вказаних роботах, цілком відповідає й твердження, що будьякий компонент освіти - це теж складна система. I якщо людське тіло є хоч і складною, але фізіологічною системою, то, наприклад, родина - це вже складна соціальна система $[1$, с. 2]. Останнім часом з'являються дослідження, у тому числі й українські, в яких той чи інший компонент освіти розглядається як складна система, наприклад, у роботі Дар’ї Підкопай з теоретичним аналізом внутрішнього розпорядку [10].

У пропонованому дослідженні предметом виступає підготовка спеціалістів медіапрофесій як складна соціальна система. Цей предмет, по відношенню до освіти, виступає компонентом, субсистемою, але такою субсистемою, яка, так само, складається з численних складних систем, що перебувають у динамічному взаємодоповнюванні, взаємопроникненні.

В українській журналістиці, відповідно до глобальної тенденції, термін «журналістика» витісняється нині терміном «медіа», а українське словосполучення «засоби масової інформації» - терміном «мас-медіа» або просто «медіа». Ще більш широкого вжитку, ніж як синонім 3МI, термін «медіа» набув як родове поняття, що об'єднує великий кластер спеціальностей, інститутів, соціальних груп у сфері соціальних комунікацій. Фахівці з обробки, зберігання, передавання та знищенні інформації, за винятком представників природничих наук і суто технічних спеціальностей, що переважно пов'язані в своїй професійній діяльності з мас-медіа - це медіафахівці. Таким чином, поняття «медіагалузь» $є$ ширшим за поняття «журналістика», а «медійник», або «медіафахівець» - ширшим за «журналіст».

Офіційно в українській освітній системі з 2016-2017 навчального року фігурувала галузь знань 0303 «Журналістика та інформація», а в ній три основні напрями підготовки: «Журналістика за видами», «Реклама і зв'язки з громадськістю (за видами діяльності)», «Видавнича справа і редагування», з такими само трьома найменуваннями спеціальності спеціаліста за дипломом [11]. За термінологією багатьох, насамперед молодих представників українського бізнесу, ринку праці, синонімом галузі знань «Журналістика та інформація» є поняття «медіагалузь», ним позначається галузь знань і практичної діяльності у сфері медіа.

Отже, навіть на рівні базових понять з питань підготовки медіафахівців існують термінологічні, тезаурусні складнощі. Це посилює відмінності «карт реальності», тобто уявлень про систему підготовки медіафахівців, у різних осіб і груп, які перебувають у безпосередніх взаємовідносинах із цією системою. Навіть у порівнянні з високою швидкістю змін у соціальній системі «українське суспільство», медіагалузь відрізняється особливо 
виразною мінливістю, динамічністю, що відображається, у тому числі, на лексичному, поняттєвому рівні. До того ж, ця галузь є не просто спорідненою, а, можна сказати, «напіврозчиненою» у величезній кількості інших галузей, вона в значній мірі накладається на них.

Спричинена глобальними революційними зрушеннями діджиталізація медіасередовища в 1990-2010-ті роки радикально позначилася на технологічних процесах у медіагалузі. Ці трансформації прискорюються, докорінно змінюючи кон'юнктуру на ринку праці медіафахівців. У зв'язку з тим, що ці зміни не завжди точно, об'єктивно висвітлюються в мас-медіа, а також через дію багатьох психологічних та економічних механізмів, українські політики, освітяни, абітурієнти та інші категорії осіб, що здійснюють великий вплив на систему підготовки медіафахівців, висувають різноманітні, суперечливі вимоги до цієї системи.

Таким чином, ефективною система підготовки медіафахівців, може бути лише тоді, коли вона є багатовекторною, поліфункціональною, а отже - інноваційною, з опертям на міцний теоретичний, дослідницький фундамент. Нижче буде проілюстровано, яких результатів дозволяє досягти подібний підхід на прикладі підготовки спеціалістів за напрямом «Реклама і зв'язки з громадськістю», що здійснюється в Інституті журналістики Київського університету імені Бориса Грінченка.

\section{Гіпотези й методи}

Через праці теоретиків складних систем проходить червоною ниткою теза про вкрай високу потребу глибокого вивчення цього явища й настільки ж високу складність у виконанні відповідного завдання. Головна проблема - у мінливості складної соціальної системи - тим більше системи такого високого ступеня складності, як підготовка кадрів для великої поліфункціональної галузі. Навіть у набагато простіших соціальних системах зміни відбуваються настільки часто, що створення універсальної довготривалої моделі, за якою можна було б розробляти ефективні плани розвитку, виглядає майже недосяжною метою.

Гіпотеза цього науково-практичного дослідження полягала в тому, що підготовка медіафахівців за напрямом «Реклама і зв'язки з громадськістю» на рівні бакалаврату в Україні є не просто складною, а надзвичайно системою; створення й розвиток потужної системи безперервного моніторингу й аналізу конкретної системи, збільшення частки ресурсів, спрямованих на це, у загальному обсязі ресурсів керівництва системи підготовки медіафахівців за напрямом «Реклама і зв'язки з громадськістю», може суттєво збільшити продуктивність цієї системи підготовки фахівців.

У літературі з аналізу складних систем освітньої галузі накопичено багато кейсів, методів, інших розробок. Однією зі вдалих спроб систематизації таких розробок є робота колективу авторів, який запропонував ділити дослідження на: а) «оперті на механізм» (кейси, лабораторні експерименти, етнографічні та інші дослідження, спрямовані на вивчення психологічних особливостей людей всередині навчального процесу - студентів, викладачів тощо, - а також на те, як соціальні явища впливають на внутрішне середовище); б) «оперті на ефект» (виділення, дослідження факторів, які впливають на академічну успішність, інші досягнення на- 
вчального закладу, зіставлення показників «на вході» 3 показниками «на виході», поєднання кількісних і якісних методів вивчення системи [4, с. 38]. Основний висновок та рекомендація цієї групи авторів: використовувати якомога більше розмаїття методів, намагатися квантифікувати дані про зв'язки між окремими особами, досліджувати процес переходу дій, зв'язків між особами й групами (мікрорівень) на рівень усієї системи (макрорівень) [4, с. 39]. А втім, це ключ до пізнання будь-якої системи: моніторинг, розуміння причин i, в результаті, відносно керована корекція того ключового для теорії складних систем явища, яке ми пропонуємо перекладати з англійської як «системна властивість» (emergent property). Зазначимо, що на сьогодні в українському науковому середовищі відсутній усталений, загальновизнаний переклад цього терміну.

У багатьох наукових працях з аналізу освіти як системи підкреслюється, що такі системи є одними з найскладніших у дослідженні у порівнянні з іншими категоріями складних систем [3, с. 128)].

Дослідження проводилося різноманітними методами аналізу публіцистичної й наукової літератури, «мозкового штурму», опитуванням кількох тисяч студентів, викладачів, а також сотень підприємців і менеджерів медійної галузі.

\section{Результати}

Пілотні дослідження, які проводилися авторами цієї роботи та багатьма їхніми колегами ще у 2015-2016 рр., виявили, наступне. Складність організації системи підготовки медіафахівців за напрямом «Реклама і зв'язки з громадськістю» визначається, серед іншого, тим, що ці спеціалісти:

- дотичні до всіх сфер суспільного життя (економічної, громадської, культурної, політичної та інших);

- більше орієнтовані на практичну, а не теоретичну діяльність;

- працюють як у державних, так і в бізнес-структурах;

- мають широку аудиторію впливу та комунікують із різними цільовими групами;

- працюють у сфері новітніх інформаційних технологій, що розвиваються швидкими темпами (діджитал-середовище).

Також протягом своєї професійної діяльності ці медіафахівці неодноразово змінюють галузь роботи. Так, із комерційної сфери вони можуть перейти працювати на аналогічну посаду до державної структури або у громадську організацію, і навпаки. I хоч перелік повноважень спеціаліста при цьому може не зазнати суттєвих змін, кожна сфера має свої особливості та вимоги до побудови комунікаційної стратегії. За таких умов медіафахівці мають вміти швидко адаптуватись до змін і вибудовувати ефективну рекламну або PR-стратегію в усіх сферах суспільного життя.

У відповідь на стратегічні зміни в освіті України, визначені державною освітньою політикою, у Київському університеті імені Бориса Грінченка з 2016 року розпочато розробку та впровадження «Нової освітньої стратегії. До її розробки були залучені науково-педагогічні та наукові співробітники. Ця стратегія спирається на нові теоретико-методологічні засади компетентністного підходу, спрямованого на підготовку конкурентоспроможних випускників університету - майбутніх фахівців різних сфер, які 
можуть ефективно працювати в умовах сучасного світу, швидко реагують на зміни в професійній діяльності, готові до постійного самовдосконалення. У зв'язку з цим:

- актуалізується навчання саме на практикоорієнтовній основі та науково-дослідній діяльності;

- зменшився відсоток навчальних годин лекційних занять та теоретичних семінарів, одночасно лекційні форми активно трансформуються у проблемні, зміст семінарських занять спрямовується на розширення лекційного матеріалу, передбачає активну самостійну роботу студентів;

- здійснено активний перехід до інтерактивних технологій з широким використанням новітнього обладнання;

- впроваджено ефективний моніторинг оцінки знань.

Останній пункт стратегї набув особливо сильного розвитку на кафедрі реклами та зв'язків з громадськістю, яка готувала в Університеті Грінченка медіафахівцв за однойменним напрямом - «Реклама і зв'язки 3 громадськістю». У результаті впровадження стратегії, загалом оновлено процес підготовки медіафахівців, який обумовив перехід до складної багатовекторної системи.

Багатовекторність - це одна з сутнісних характеристик освітнього середовища сучасного університету [12]. Нею обумовлене створення взаємопов'язаних між собою мікросистем у складній системі підготовки медіафахівців. Розглянемо характер даних мікросистем в організаційно-змістовому вимірі на прикладі підготовки спеціалістів у галузі реклами та зв'язків з громадськістю, що здійснюється в Інституті журналістики Київського університету імені Бориса Грінченка.

До переліку мікросистем складної системи фахової підготовки за освітньо-професійною програмою 061.00.02 «Реклама і зв'язки з громадськістю» спеціальності 061 «Журналістика» (введеною в дію з 01.09.2017р., наказом від 26.05.2017 р. № 348) входять такі:

\section{I рівень - бакалаврський}

1. Обов'язкова, нормативна, відповідно до встановлених в Україні освітніх стандартів (мікросистема визначає теоретико-прикладний зміст фахової підготовки).

2. Варіативна, спеціалізація (мікросистема 3 формування додаткових фахових компетентностей спеціалізацій).

2.1. Спеціалізація «Сучасні івент-практики» (основу мікросистеми складають знання основ івентології; володіння креативними технологіями в організації та проведенні спеціальних заходів, сценарною майстерністю, режисурою постановки різних форм eventпрактик).

2.2. Спеціалізація «Digital продакшн» (основу мікросистеми складають знання основ цифрової індустрії, здатність формувати digitalстратегії та застосовувати відповідний інструментарій при виробництві й просуванні контенту; володіння 3Dтехнологіями в рекламі, інструментарієм WEB-дизайну) [9].

3. Практична (зміст мікросистеми складають чотири види практики: навчальна, виробнича, практика зі спеціалізації, переддипломна). 
4. Вибіркова (ця мікросистема забезпечує процес індивідуалізації навчання,задоволення освітніх і кваліфікаційних потреб студента, враховує можливості й традиції університету, регіону).

5. Проєктна (підготовка і захист бакалаврського проєкту). Ця мікросистема є завершальною.

\section{II рівень - магістерський}

1. Обов'язкова, нормативна.

2. Варіативна (мікросистема з формування додаткових фахових компетентностей спеціалізацій, забезпечує право студента на вільний вибір).

2.1. Спеціалізація «Рекламно-поліграфічні послуги» (основу даної мікросистеми складають знання специфіки рекламно-поліграфічних послуг і здатність їх надавати).

2.2. Спеціалізація «Прес-секретарство та публічні комунікації (професійний зміст зазначеної мікросистеми складають знання публічних комунікації та їх застосування у прес-секретарстві).

3. Практична.

4. Проєктна (підготовка і захист магістерського проєкту у форматі «стартапу»).

Отже, зазначений вище перелік мікросистем у дворівневому вимірі підтверджує складний характер системи фахової підготовки медіафахівців у Київському університеті імені Бориса Грінченка, зокрема за освітньопрофесійною програмою «Реклама і зв'язки з громадськістю».

Відповідно до Нової освітньої стратегії Університету, викликів і вимог сучасного ринку праці, а також моніторингу й аналізу попереднього досвіду, загальним вектором організації підготовки медіафахівців за напрямом «Реклама і зв'язки з громадськістю» стала практикоорієнтованість навчалъного процесу. Нею обумовлено і ряд інновацій в складній системі підготовки майбутніх спеціалістів, запроваджених кафедрою реклами та зв'язків з громадськістю.

Першочергові зміни стосувались якості викладацького складу. Адже від професійного й освітнього рівня науково-педагогічних працівників залежить якість підготовки майбутніх фахівців. Оскільки, медіасфера є системою мобільною, рухомою, нерозривно пов'язана із розвитком сучасних інформаційних технологій та змінюється швидше, аніж з'являються нові наукові напрацювання, університет активно долучає до роботи викладачівпрактиків. Це спеціалісти, які працюють у PR-агенціях (зокрема, «DIALLA Communications»), прес-службі Верховної Ради України, бізнес-структурах, обіймають посади начальників управлінь комунікаційних відділів Київської міської державної адміністрації та ін. Станом на січень 2020 року, 38\% співробітників кафедри реклами та зв'язків з громадськістю є практикуючими спеціалістами. Що ж стосується навчального навантаження, то викладачі-практики читають $33 \%$ загального об'єму годин кафедри. Для порівняння зазначимо, що у 2016 році лише $8 \%$ викладачів кафедри, були практикуючими спеціалістами. На них припадало $4 \%$ загального об'єму годин навчального навантаження. Збільшення серед викладачів числа практикуючих спеціалістів, які мають різний професійний досвід 
у сферах бізнесу, державного управління та місцевого самоврядування, дозволяє вповні реалізувати обраний вектор організації навчального процесу. Впровадженню цих інновацій передували дослідження та моніторинг, які показали необхідність змін у кадровій політиці кафедри.

Різноманітність базової освіти науково-педагогічних співробітників кафедри реклами та зв'язків з громадськістю Інституту журналістики Київського університету імені Бориса Грінченка також дозволяла враховувати поліфункціональність, складність завдань, які постають перед молодими спеціалістами і багатопрофільністьїх діяльності. Базова освіта за медійним, історичним, економічним, філологічним, психологічним, політичним, культурологічним та іншими напрямами дозволили забезпечити високий рівень викладання спеціальних дисциплін. Окрім того, поєднання такої освіти з практичним досвідом дозволили забезпечити студентів знаннями того, як працюють реклама та PR у гуманітарній, громадсько-політичній, державній і комерційній сферах.

Зростали вимоги й до тих науково-педагогічних працівників, які мають суто вишівський досвід роботи. Постійно збільшувалася кількість монографій, наукових статей, написаних і опублікованих викладачами кафедри, підвищується якість досліджень та наукових розвідок. Це дозволило забезпечити гідний рівень як практичних навичок, так і теоретичних знань студентів.

Нова система підготовки медіафахівців в університеті спрямувала організацію освітнього процесу для першого рівня вищої освіти на практикоорієнтований характер, реалізувати який дозволяє відповідна схема: «аудиторія $\rightarrow$ центри компетентностей $\rightarrow$ бази практик». Створення центрів компетентностей (далі - Центрів) в Інституті журналістики, як структурного підрозділу Київського університету імені Бориса Грінченка, який забезпечував підготовку медіафахівців, мав системний характер і створював умови для формування конкурентоспроможності випускників для медіасфери. Це:

- Центр сучасних комунікацій;

- Центр мультимедійних технологій;

- Навчальна лабораторія радіомовлення;

- Інформаційно-аналітичний центр;

- Навчально-виробнича майстерня «Грінченко-Інформ».

Діяльність Центрів була підпорядкована створенню квазіпрофесійного середовища, базувалася на міждисциплінарних зв'язках у галузі масмедіа та застосуванні інноваційних методів навчання. Міждисциплінарність сприяла розумінню студентами цілісності медіасфери як сфери майбутньої професійної діяльності.

Подібні організаційні структури демонструють відповідність Декларації конференції ЮНЕСКО з питань вищої освіти (1998), яка серед принципів сучасної освіти визначає інноваційність, міждисциплінарність та трансдисциплінарність. Крім того, Болонськими документами міждисциплінарність розглядається як одна з бажаних ознак нової якості вищої освіти. На думку Л. I Яковенко., «ії неформальна реалізація - вимога часу, однак перехід від усвідомлення необхідності до практичної реалізації міждисциплінарності досить суперечливий» [13, с. 29]. Ця суперечливість 
в освітньому просторі підготовки медіафахівців вирішена Київським університетом імені Бориса Грінченка через створення Центрів компетентностей.

Проаналізуємо детальніше діяльність деяких із них. Зокрема, Центр сучасних комунікацій забезпечує міждисциплінарні зв'язки таких навчальних предметів, як «Ораторське мистецтво», «Сучасна прес-служба», «Психологія комунікацій», «Спічрайтинг», «Професійні стандарти», «Іміджологія», «Кризові комунікації, «Управління інформацією», «Event-практики». Центр розрахований на 120 посадкових місць, 76 з них оснащені мікрофонами; встановлені система ПК та програмне забезпечення; аудіосистема із мобільними та стаціонарними мікрофонами; відеосистема (три екрани 4 м х 3 м; 3 м х 2,5 м; три проєктори; дві рухомі відеокамери); кондиціювання повітря; технічне забезпечення синхронного перекладу двома мовами; система онлайн-трансляції та скайп-зв'язку. Таке матеріально-технічне обладнання Центру забезпечує проведення сучасних форм навчання, зокрема: інтерактивних дискусій, рольових ігор, воркшопів, консультацій, тренінгів, творчих майстерень, коучингу тощо.

Отже, Центр сучасних комунікацій, як складна мікросистема, забезпечує формування таких компетентностей майбутніх фахівців за освітньопрофесійною програмою «Реклами і зв'язки з громадськістю»:

- створення ефективних рекламно-інформаційних продуктів;

- підготовка планів і проєктів з реклами й зв'язків з громадськістю для державних, комерційних та неурядових структур;

- оволодіння інструментарієм іміджмейкінгу та репутаційного менеджменту;

- організація і проведення комунікаційних заходів (публічних виступів, прес-конференцій, круглих столів, конкурсів);

- оволодіння технологіями створення та управління комунікаційними агентствами, рекламними й PR-структурами;

- здійснення кризової комунікації в умовах надзвичайних ситуацій.

Наступним кроком у організації складної системи підготовки медіафахівців за напрямом «Реклама і зв'язки з громадськістю» стало впровадження нових спеціалізацій з урахуванням вимог сучасного ринку праці. Зокрема, це такі спеціалізації як: «Публічні комунікації та прес-секретарство», «Сучасні івент-практики», «Digital продакшн», «Сучасний брендинг».

Кожен із цих напрямів й сьогодні динамічно розвивається. Традиційні форми публічних заходів зазнають трансформацій, з'являються нові формати, наприклад, івенти, які проходять не тільки в офлайн, а й в онлайн-режимі. Також фактично кожні півроку відбувалися суттєві зміни в алгоритмах роботи digital-інструментів, з якими працюють медіафахівці, з'являлися нові технології. У свою чергу, впровадження спеціалізації «Сучасний брендинг» в освітній процес було відповіддю на запит роботодавців, що зацікавлені у фахівцях, які спеціалізуватимуться на побудові корпоративного й особистого бренду.

Непростим, але перспективним напрямом інвестицій є збільшення годин практики поза межами ВНЗ. Практикоорієнтований підхід до навчального процесу передбача, що після набуття теоретичних знань, роботи на 
практичних заняттях у навчальних аудиторіях і Центрах компетентностей університету, студенти долучаються до роботи на різних підприємствах, в агенціях, установах. Аби студенти міг набути практичних навичок за всіма вивченими напрямами, вони проходили практику в державній, гуманітарній, політичній та бізнес-сферах. Це дало можливість вийти на новий професійний рівень, реалізувати власні медіа-проєкти. Окрім того, викладачі залучали студентство до участі у волонтерських проєктах, організації професійних форумів та інших заходів, де майбутні фахівці можуть реалізувати на практиці набуті знання. Усі ці інновації здійснювалися, виходяч з результатів дослідженя думок, потреб, запитів абітурієнтів, судентів, випускників, роботодавців.

Однією з важливих складових реалізації Нової освітньої стратегії була діджиталізація навчального процесу. Для забезпечення високого рівня якості підготовки медіафахівців, Київський університет імені Бориса Грінченка не лише вдосконалював матеріально-технічну базу, а й впроваджував у навчання електронні курси, що відповідали світовим тенденціям діджиталзації, запровадження дистанційних форм навчання . На базі платформи LMS Moodle (Modular Object-Oriented Dynamic Learning Environment) організовано систему електронного навчання. Студенти й викладачі завжди мають дистанційний доступ до матеріалів навчального курсу. Протягтм 2017-2019pр. викладачі профільної кафедри активно працювали над розробкою нових електронних курсів, кожен із яких проходив відповідну, багаторівневу сертифікацію, в якій оцінювалися й технічні, навчальнометодичні аспекти матеріалу. У порівняльному графіку на Рис. 3 відображено позитивну динаміку розробки ЕНK за 2017-2019 pp. Не менш важливою є якість контенту, представленого у розроблених курсах. Згідно з результатами опитувань студентів, у 2019 р. середня оцінка ЕНК зросла до 4,61 балів у порівняння з 4,52 балів і 2017 р.

Значним поступом у організації підготовки фахівців у галузі реклами та зв'язків з громадськістю стало впровадження англомовних курсів у освітній процес. Студенти отримали можливість обрати мову, якою вони проходитимуть курс. Прикладом варіативного читання курсу українською та англійською мовами може слугувати викладання дисциплін «Копірайтинг» та «ІІторія реклами та $\mathrm{PR}$. Практика двомовного читання дисципліни, з одного боку, ускладнює процес організації навчального процесу, а з іншого - дозволяє забезпечити кращу підготовку медіафахівців до роботи не лише на українському, а й міжнародному ринку праці.

Для того, аби простежити ефективність впроваджених інновацій в освітній процес, у Київському університеті імені Бориса Грінченка було розроблено система соціологічних опитувань, яка в свою чергу постає субсистемою в складній системі підготовки медіафахівців. Контроль і аналіз зворотнього зв'язку дозволяють відслідковувати проміжні результати, своєчасно корегувати роботу системи, вдосконалювати освітній процес.

Опитування проводяться на декількох рівнях:

- загально-університетський;

- інститутський;

- кафедральний;

- студентський. 
У 2016 році активізувалася робота низки підрозділів, спрямована на вивчення - шляхом соціологічних опитувань - багатьох аспектів навчального процесу, наукової, методичної роботи викладачів тощо. Найбільш активними у проведені таких опитувань у 2016-2019 рр. були: Навчальнонауковий центр культури лідерства Факультету інформаційних технологій,Науково-методичний центр стандартизації та якості освіти, Науководослідна лабораторія інформатизації освіти, Бібліотека, Науково-методичний центр досліджень, наукових проєктів та програм. Серед проблемних питань, які вивчалися в ході опитувань: вибір і запровадження цифрових технологій у навчальний процес; вивчення потреб співробітників університету в підвищенні кваліфікації; технології оцінювання начальних досягнень студентів; Стратегія ефективного використання технологій дистанційного навчання; використання інструментів пошуку в процесі дослідження.

Протягом 2016-2019 рр. в Університеті Грінченка вдосконалювалася складна система моніторингу досягнень викладачів, безпосередньо спрямована на щорічне формування рейтингу «Лідер року». Ця система, у свою чергу, була частиною системи більш складної - моніторингу діяльності викладачів.

Одним зі складників рейтингу «Лідер року» були результати опитувань «Викладач очима студентів» щодо сприймання кожного викладача студентами, за підсумками навчального року. Такі опитування проводилися наприкінці кожного семестру, з різними студентськими групами та викладачами - об'єктами оцінювання, залежно від того, в яких групах і в якому семестрі викладала та чи інша особа.

Проте, враховуючи особливу складність підготовки медіафахівців, керівництво кафедри реклами та зв'язків з громадськістю, на додачу до нижчезгаданих загальноуніверситетських дій з моніторингу, розробило й запровадило низку анкет для вимірювання доцільності тих чи інших навчальних дисциплін і професійної діяльності викладачів саме цієї кафедри. Такі опитування проводилися в 2017-2019 рр. наприкінці навчального року серед студентів кафедри.

Питання анкети, в якій студентам пропонувалися оцінити за 5-бальною шкалою кожний предмет і викладача: «1. Нижче названі предмети цього навчального року. Наскільки цікаві, змістовні ці лекції та семінари? 2. Як ви оцінюєте рівень комунікацій, діалогу, доброзичливості викладача у ставленні до студентів? 3. Наскільки б ви хотіли продовжити навчання у цього викладача в наступні роки? 4. Інше (власні думки, пропозиції».

Деякі викладачі також поводили короткі письмові опитування студенів на початку та/або наприкінці вивчення своїх навчальних дисциплін для удосконалення своєї роботи.

Окрім того, керівники робіт студентів - учасників всеукраїнських конкурсів наукових робіт, а також керівники бакалаврських кваліфікаційних робіт заохочували проведення опитувань студентами, в тому числі спрямованих на вивчення думок студентів і викладачів.

За результатами як індивідуальних, так і кафедральних, і загальноуніверситетських анкетувань, невідкладно вносилися корективи до освітніх програм, кадрової роботи, інших напрямів підготовки медіафахівців.

Загалом, кількість опитувань у процесі підготовки медіафахівців в Київському університеті імені Бориса Грінченка протягом 2016-2018 років 
зросла на 60-80\%, покращувалася також і якість цих моніторингових інструментів. Цілеспрямовано підвищувалася швидкість реакції на виявлені особливості студентського й викладацького складу, негативні й позитивні прояви в діяльності кафедри, інституту, університету. У такий спосіб підвищувалася контрольованість, керованість у складній системі, якою є підготовка медіафахівців.

Визначальним фактором ефективності й доцільності функціонування такої складної системи моніторингу стала позитивна динаміка змін, яка спостерігається в освітньому процесі. Розглянемо її детальніше на прикладі декількох масштабних соціологічних опитувань, що проводились серед студентів університету.

Одним з основних індикаторів ефективності впровадження Нової освітньої стратегії та цілісного розвитку культури освітнього процесу в університеті є вищезгадане опитування «Викладач очима студента». У 2018 році в опитуванні взяли участь 6746 студентів, які оцінювали роботу 794 викладачів університету та університетського коледжу за п'ятибальною шкалою, у 2019 році до опитування долучилось 6955 студентів та 150 аспірантів, які оцінювали 813 викладачів. Згідно з результатами опитування 2018 року, $63 \%$ осіб мали рейтинговий бал у діапазоні 4,5-5. У 2019-му цей показник виріс до $65,23 \%$. Рейтинговий бал у діапазоні 4,0-4,49 у 2018-му і 2019 роках становив $28 \%$ та $27,03 \%$ відповідно. Скоротився відсоток викладачів, які мають рейтинговий бал нижче 4,0. У 2018 р. цей показник становив $9 \%$, а у 2019-му зменшився до $7,74 \%[6,7]$. Анкета опитування побудована таким чином, аби мінімізувати відсоток суб'єктивних чинників в оцінюванні. Результати опитування передаються в структурні підрозділи, де надалі вживаються відповідні заходи.

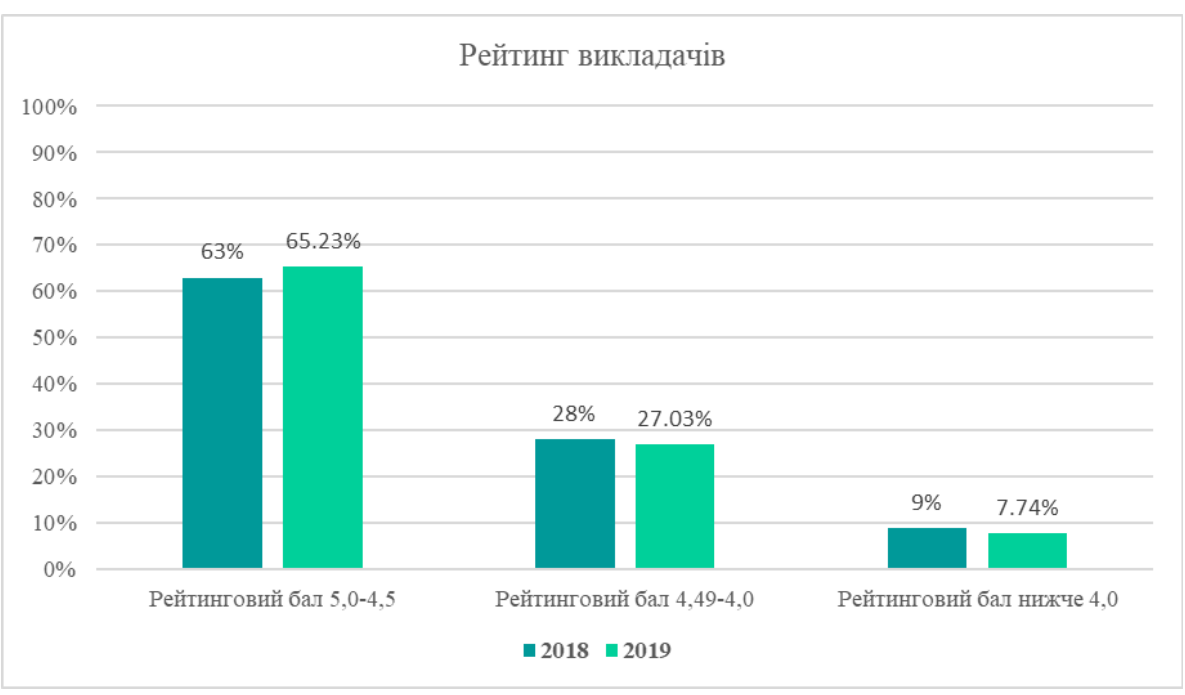

Рис. 1. Порівняльна діаграма даних опитувань «Викладач очима студентів» за 2018 і 2019 pp.

Окрім того, адміністрація систематично проводить аналіз якісного складу співробітників університету, що знаходить своє відображення у річних звітах ректора. 
Також у грудні 2019 року адміністрацією університету було проведено опитування студентів-третьокурсників, які три роки навчаються за Новою освітньою стратегією Університету. У опитування взяли участь $74 \%$ студентів від загальної кількості третьокурсників. Результати опитування підтверджують, що студенти відчувають практичну орієнтованість занять [7].

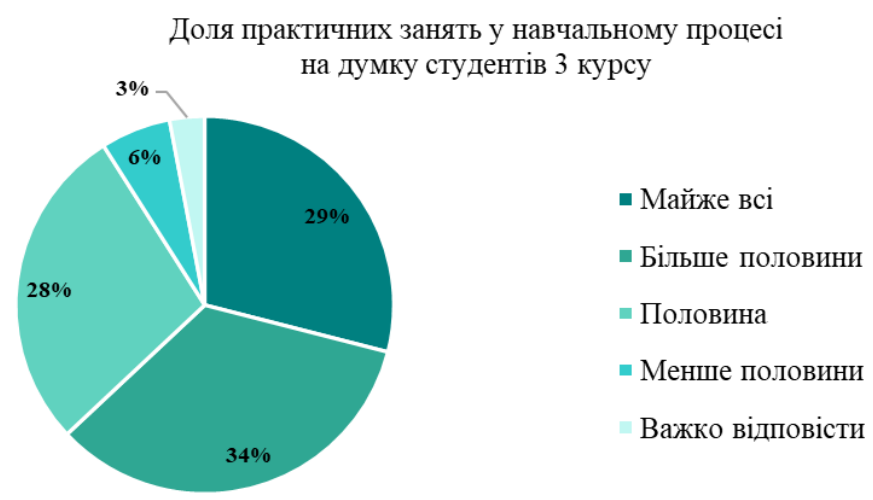

Рис. 2. Результати опитування студентів щодо практичної спрямованості навчання (2019р.)

Ще одним важливим показником ефективності реалізації Нової освітньої стратегії та інноваційного підходу до освітнього процесу Київського університету імені Бориса Грінченка є реалізація системи дистанційного навчання. Зокрема, розробка електронних навчальних курсів. Спостерігається постійна позитивна динаміка в розробці ЕНК протягом 20172019 pp. [7].

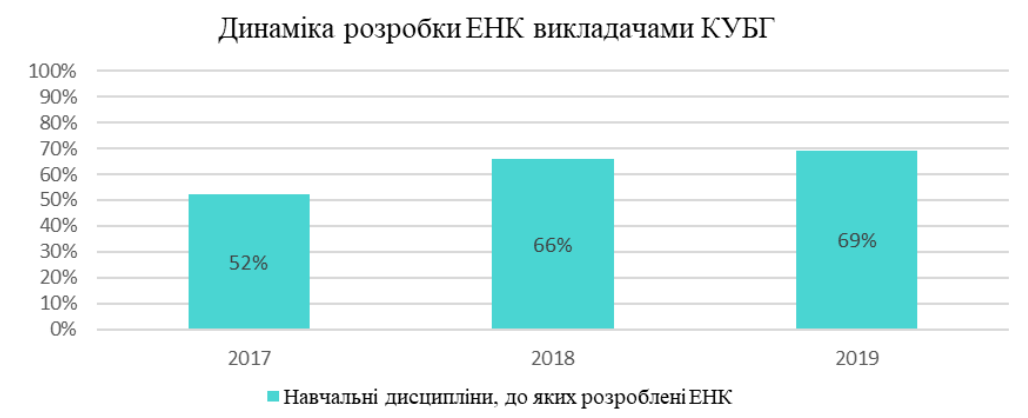

Рис. 3. Порівняльний графік показників розробки ЕНК викладачами КУБГ за 2017-2019 pp.

\section{Висновки}

У ході кількарічного дослідження й майже паралельного, інколи протягом кількох днів, невідкладного впровадження його проміжних результатів, доведено наступне. Підготовка медіафахівців за напрямом «Реклама і зв'язки з громадськістю» на рівні бакалаврату в Україні є не просто складною, а надзвичайно складною системою. Тому створення й розвиток потужної системи безперервного моніторингу й аналізу конкретної системи, 
збільшення частки ресурсів, спрямованих на це, у загальному обсязі ресурсів керівництва системи підготовки медіафахівцв за напрямом «Реклама і зв'язки з громадськістю», значно збільшує продуктивність цієї системи підготовки фахівців. Постійний моніторинг функціонування цієї складної системи, безперервний систематичний аналіз отриманих даних і своєчасне корегування дій дозволили досягти результатів, які добре піддаються вимірюванню й порівнянню з результатами попередніх років.

1) Виріс конкурс на одне місце серед вступників. За даними моніторингу вступної кампанії 2019 року, загальний конкурс серед вступників на освітню програму «Реклама і зв'язки з громадськістю» становив 15 людей на одне місце, й університет за цим показником, цієї освітньою програмою, вперше став лідером серед українських вишів.

2) Зросли показники результатів ЗНО серед абітурієнтів. У 2019 р. найвищий бал серед вступників на спеціальність «Реклама і зв'язки з громадськістю» склав 200 балів. Також збільшився середній рейтинговий бал вступників як на бюджетну, так і на контрактну форму навчання. У 2018 році середній рейтинговий бал вступників на бюджетну форму навчання становив 185,7 балів, у 2019-му показник виріс до 191,97 балів. Відповідні показники за контрактною формою навчання у 2018-му році - 173,6 бали, у 2019-му - 175,98 балів [8].

3) Збільшився відсоток вступників із високим рівнем володіння англійською мовою. За результатами вступної кампанії 2019 року, у $65 \%$ студентів 1 курсу спеціальності «Реклама і зв'язки з громадськістю» показники ЗНО з англійської мови становлять 175 балів і вище. У 2016 р. цей показник не перевищував $30 \%$.

4) Зросла кількість студентів, що отримують нагороди на спеціалізованих студентських конкурсах та фестивалях.

5) Студентів активно долучаються до розробки реальних рекламних проєктів (зокрема: створення зовнішньої реклами для Київського міського центру крові, рекламних проєктів КМДА та ін.).

Наведені вище основні результати слугують підтвердженням того, що постійний потужний комплексний моніторинг мікро- й макросередовища та своєчасне, невідкладне розроблення й впровадження коректив, як відповідь на отримані результати, забезпечують ефективне продуктивне функціонування навіть такої складної системи, якою є підготовка медіафахівців в українському вищому навчальному закладі в складному, високодинамічному макросередовищі. Автори рекомендують менеджерам освіти, викладачам, адміністраторам вищих навчальних закладів, збільшувати частку ресурсів, спрямованих на моніторинг діяльності системи підготовки фахівців у своїх закладах і на прискорення відповідного корегування системи. 


\section{Література}

[1] Bar-Yam, Y. 2003. Dynamics of complex systems. Reading, MA: AddisonWesley.

[2] Jacobson, M., Levin, J., \& Kapur, M. 2019. Education as a Complex System: Conceptual and Methodological Implications. Educational Researcher, 48(2), 112-119. DOI: 10.3102/0013189×19826958. Retrieved from https: //escholarship.org/uc/item/9p13163x.

[3] Lemke, J., \& Sabelli, N. 2008. Complex systems and educational change: Towards a new research agenda. Educational Philosophy and Theory, 40(1), 118-129. DOI: 10.1111/j.1469-5812.2007.00401.x.

[4] Maroulis, S., Guimerà, R., Petry, H., Stringer, M. J., Gomez, L., Amaral, L. A. N., Wilensky, U. 2010. Complex systems view of educational policy research. Science, 330, 38-39.

[5] Sayama, Hiroki. 2015. Introduction to the Modeling and Analysis of Complex Systems. Open SUNY Textbooks, Milne Library. State University of New York at Geneseo, 2015, 498 p.

[6] Звіт за 2018 рік ректора Київського університету імені Бориса Грінченка, доктора філософських наук, професора, дійсного члена (академіка) НАПН України Огнев'юка Віктора Олександровича. http:// kubg.edu.ua/images/stories/Departaments/zvit_2018n.pdf.

[7] Звіт за 2019 рік ректора Київського університету імені Бориса Грінченка, доктора філософських наук, професора, дійсного члена (академіка) НАПН України Огнев'юка Віктора Олександровича. http:// kubg.edu.ua/images/stories/Departaments/zvit-2019n.pdf.

[8] Звіт про діяльність Інституту журналістики за 2019 piк. http://ij.kubg. edu.ua/images/phocagallery/Podii2020/zvit_dyrektora_2019.pdf.

[9] Освітньо-професійна програма 061.00.02 Реклама і зв'язки з громадськістю першого (бакалаврського) рівня вищої освіти. Київський університет імені Бориса Грінченка. 2017. http://kubg.edu.ua/images/stories/ Departaments/vstupnikam/ij/2019/opp_rzg_bak.pdf.

[10] Підкопай Д. С. 2014. Суттєві ознаки внутрішнього трудового розпорядку як правового явища. Науковий вісник Ужгородсъкого національного університету. Серія: Право. 27(2), 72-76. http://nbuv.gov. ua/UJRN/nvuzhpr_2014_27\%282\%29__19.

[11] Про особливості запровадження переліку галузей знань і спеціальностей, за якими здійснюється підготовка здобувачів вищої освіти, затвердженого постановою Кабінету Міністрів України від 29 квітня 2015 року № 266. https://zakon.rada.gov.ua/laws/show/z1460-15.

[12] Шульга Н. Д. Сутнісні характеристики поняття «державна освітня політика». http://academy.gov.ua/ej/ej14/txts/Shulga.pdf.

[13] Яковенко Л. І. 2007. Міждисциплінарність та необхідність її реалізації в освіті. Матеріали II Всеукраїнської науково-практичної конференції «Соціально-економічні трансформації в епоху глобалізації». Полтава: Скайтек. 1, 25-31. http://dspace.pnpu.edu.ua/bitstream/123456789/2842/ $1 /$ Jakovenko.pdf. 


\section{References}

[1] Bar-Yam, Y. 2003. Dynamics of complex systems. Reading, MA: AddisonWesley.

[2] Jacobson, M., Levin, J., \& Kapur, M. 2019. Education as a Complex System: Conceptual and Methodological Implications. Educational Researcher, 48(2), 112-119. DOI: 10.3102/0013189×19826958. Retrieved from https://escholarship.org/uc/item/9p13163x.

[3] Lemke, J., \& Sabelli, N. 2008. Complex systems and educational change: Towards a new research agenda. Educational Philosophy and Theory, 40(1), 118-129. DOI: 10.1111/j.1469-5812.2007.00401.x.

[4] Maroulis, S., Guimerà, R., Petry, H., Stringer, M. J., Gomez, L., Amaral, L. A. N., Wilensky, U. 2010. Complex systems view of educational policy research. Science, 330, 38-39.

[5] Sayama, Hiroki. 2015. Introduction to the Modeling and Analysis of Complex Systems. Open SUNY Textbooks, Milne Library. State University of New York at Geneseo, 2015, 498 p.

[6] Zvit za 2018 rik rektora Kyivskoho universytetu imeni Borysa Grinchenka, doktora filosofskykh nauk, profesora, diisnoho chlena (akademika) NAPN Ukrainy Ogneviuka Viktora Oleksandrovycha. http://kubg.edu.ua/images/ stories/Departaments/zvit_2018n.pdf.

[7] Zvit za 2019 rik rektora Kyivskoho universytetu imeni Borysa Grinchenka, doktora filosofskykh nauk, profesora, diisnoho chlena (akademika) NAPN Ukrainy Ogneviuka Viktora Oleksandrovycha. http://kubg.edu.ua/images/ stories/Departaments/zvit-2019n.pdf.

[8] Zvit pro diialnist Instytutu zhurnalistyky za 2019 rik. http://ij.kubg.edu. ua/images/phocagallery/Podii2020/zvit_dyrektora_2019.pdf.

[9] Osvitno-profesiina prohrama 061.00.02 Reklama $\overline{\mathrm{i}}$ zviazky z hromadskistiu pershoho (bakalavrskoho) rivnia vyshchoi osvity. Kyivskyi universytet imeni B. Grinchenka. 2017. http://kubg.edu.ua/images/stories/Departaments/ vstupnikam/ij/2019/opp_rzg_bak.pdf

[10] Pidkopai D.S. 2014. Suttievi oznaky vnutrishnoho trudovoho rozporiadku yak pravovoho yavyshcha. Naukovyi visnyk Uzhhorodskoho natsionalnoho universytetu. Seriia : Pravo. 27(2),72-76. http://nbuv.gov.ua/ UJRN/nvuzhpr_2014_27\%282\%29 19.

[11] Pro osoblyvosti zaprovadzhennia pereliku haluzei znan i spetsialnostei, za yakymy zdiisniuietsia pidhotovka zdobuvachiv vyshchoi osvity, zatverdzhenoho postanovoiu Kabinetu Ministriv Ukrainy vid 29 kvitnia 2015 roku № 266. https://zakon.rada.gov.ua/laws/show/z1460-15.

[12] Shulha N. D. Sutnisni kharakterystyky poniattia «derzhavna osvitnia polityka». http://academy.gov.ua/ej/ej14/txts/Shulga.pdf.

[13] Yakovenko L. I. 2007. Mizhdystsyplinarnist ta neobkhidnist yii realizatsii v osviti. Materialy II vseukrainskoi naukovo-praktychnoi konferentsii «Sotsialno-ekonomichni transformatsii v epokhu hlobalizatsii». Poltava: Skaitek. 1, 25-31. http://dspace.pnpu.edu.ua/bitstream/123456789/2842/1/ Jakovenko.pdf. 